\title{
The Implications of Social Media Marketing on Fashion Brand Purchase
}

\author{
V. Vijay Durga Prasad, S. Praveen
}

\begin{abstract}
Social networking sites today are one of the "best opportunities" for a brand to connect with potential consumers. Social media is a medium for communication. Fashion industry has increasingly adopted customer engagement levels in Social networking sites to achieve superior firm performance. The buyer points out the differences between social networks and the launch of new social projects with speed. Social media marketing and the companies that use it have become more sophisticated. This study mainly aims to know the impact of social network marketing and consumer engagement on consumer purchase intention.
\end{abstract}

Keywords---Social network marketing, Consumer engagement, Consumer purchase intention

\section{INTRODUCTION}

Social networking is now developing so well that it becomes an important aspect of our daily lives. It is estimated that in 2019 there will be around 2.77 billion social network users in the world, compared to 2.46 billion in 2017. In 2017, 71 percent of Internet users are users of social networks, and this figure is expected to increase. Facebook is the first social network that has 2.2 billion monthly active users. The Instagram photo sharing application has 1 billion active users. More than 2 billion Internet users use social networks. Printerest is the fastest, independently launched site, which reaches 10 million unique visitors per month. Twitter has more than 555 million users with 5,700 new tweets per second.

According to (Rubathee Nadaraja, 2013), social networking is a platform that social network channels use to promote a company and its products or services. Social interrelated websites such as Facebook and Twitter have changed the way of thinking about commercial advertising. Certainly, some companies get more customers to their social networking sites than on their own website. The benefits of social media marketing are lower costs and greater reach. The cost of social media is usually lower than other marketing platforms such as personal vendors or distributors. In addition, social marketing allows companies to reach customers that cannot be accessed due to time and placements of existing distribution channels.

Social media platforms are becoming more advanced as we move into the future, allowing a fast-growing fashion industry to enter various consumer markets with just a few clicks. Customers communicate with fashion houses on a personal and interactive level. Social media marketing

Revised Manuscript Received on July 10, 2019.

V. Vijay Durga Prasad, Professor, Department of Management Studies, PSCMR College of Engineering \& Technology, Vijayawada, Andhra Pradesh India.

S. Praveen, Assistant Professor, Department of Management Studies, PSCMR College of Engineering \& Technology, Vijayawada, Andhra Pradesh India. campaigns not only increase brand equity, but also strengthen connections between users in the network, while users identify themselves with brands and become loyal customers.

Social media becomes best platform to acquire and convert customers with measuring and optimizing social media with the purpose of satisfying customers to retain them loyal for life time. This study is helpful to know how consumers are engaging themselves in social networking sites related to fashion brands and how fashion brands are influencing customers by social network marketing and to know these impacts on consumer purchase intension.

\section{REVIEW OF LITERATURE}

Social network marketing means the information can be sent to people around the world. By utilization of social network marketing, organizations will change their way towards customer needs and the wants they respond to customers and to their competitors. Social Network Marketing offers marketers the ability to reach more viewers and enable them to use valuable information and build relationships with their customers. Using social network marketing, interactions in the virtual world can share their views and perceptions. Social Network Marketing $-\diamond$ Customer Relationship Management Intention Purchasing intent is the effective route for purchase intent (Mirza Ashfaq Ahmed, 2014).

The influence of social media and social networks on buying decisions increases, while the influence of this purchase decision on customer satisfaction also increases (Susanti, 2017). It made easy for marketers to identify people of groups who in turn act as an influencer to their product/services and help in organic growth of the brand. It is cost free because all the social networking sites are free to use. By using social network marketing, marketers are in constant interaction with the customers in order to understand their needs and hence produce good products which match the needs of the customers. The best way to learn from your customers about their needs and drawbacks of organization (Neti, 2011).

The digital marketing of the fashion industry has changed so much that the brand uses an account on social networks to sell clothes. By offering quality content like videos, blogs, quotes and free giveaways the customer engagement can be generated. To appeal audience digitally it requires investment of time and money to build the customer base. If twitter is considered marketer can concentrate on the news
Blue Eyes Intelligence Engineering \& Sciences Publication 
and update about the brand and its promotions. Keep your social networking site active by regularly publishing and updating subscribers about your brand and other relevant content. You can do it simply by asking a simple question related to recent events or answering comments.

\section{OBJECTIVES OF THE STUDY}

- To study the relationship and impact between social network marketing on consumers.

- To observe the influence of demographic factors on social networking purchasing.

\section{METHODOLOGY \& RESULTS}

The population size in Vijayawada is $1,00,000$. The Sample sizes of 150 questionnaires were distributed out of which 122 were responded. The sample size is 122 . Convenience sampling is done for the study. As the research is related to social media the respondents who are internet users were considered.

\section{Demographics Of The Respondents:}

From a total 756 respondents about 70.1 percent are male and the rest 29.9 percent are female. With respect to age of the respondents about 36.8 percent are in the age of 25-35 years and majority 40.7 percent are in the age of 35-45 years of age. All the respondents about 92.6 percent are married and the rest are not. It is amazing that about 33.3 percent of the consumers are graduates and the rest about 61.6 percent are SSC Qualified. About 45.8 of the respondents earn Rs. 20,000 to 30,000 of salary and finally about 45.8 percent possess 2-5 years of experience in brand purchasing in repeated and occasional times.

\section{Descriptive Analysis: Testing Hypothesis:}

H1: Perceived Usefulness of Social Media Marketing in Brand purchasing.

Table 1: Perceived Usefulness of Social Media Marketing in Brand purchasing

\begin{tabular}{|c|c|c|c|c|c|c|c|c|}
\hline \multicolumn{2}{|c|}{ Demographic Description } & $\begin{array}{c}\text { Total } \\
\text { sample } \\
n=756\end{array}$ & $\begin{array}{c}\text { Very } \\
\text { much } \\
\text { Unlikely }\end{array}$ & Unlikely & Neutral & Likely & $\begin{array}{c}\text { Very } \\
\text { much } \\
\text { Likely }\end{array}$ & $\begin{array}{c}\text { Chi } \\
\text { Square }\end{array}$ \\
\hline \multirow{3}{*}{$\begin{array}{l}\text { Qualificatio } \\
\mathrm{n}\end{array}$} & SSC & $466(61.64)$ & $0(0)$ & $21(4.51)$ & $41(8.8)$ & $319(68.45)$ & $85(18.24)$ & \multirow{3}{*}{$\begin{array}{c}22.225, \mathrm{df} 8 \\
,<0.05\end{array}$} \\
\hline & Graduates & $252(33.33)$ & $6(2.38)$ & $12(4.76)$ & $21(8.33)$ & $152(60.32)$ & $61(24.21)$ & \\
\hline & PG & $38(5.03)$ & $0(0)$ & $0(0)$ & $7(18.42)$ & $24(63.16)$ & $7(18.42)$ & \\
\hline \multirow{4}{*}{$\begin{array}{l}\text { Monthly } \\
\text { Income }\end{array}$} & $\begin{array}{l}\text { Rs. } 20,000- \\
30,000\end{array}$ & $346(45.77)$ & $2(0.58)$ & $11(3.18)$ & $26(7.51)$ & $238(68.79)$ & $69(19.94)$ & \multirow{4}{*}{$\begin{array}{c}24.990, \mathrm{df} 1 \\
2,<0.05\end{array}$} \\
\hline & $\begin{array}{c}\text { Rs } 30,000- \\
40,000\end{array}$ & $244(32.28)$ & $0(0)$ & $12(4.92)$ & 29(11.89) & $155(63.52)$ & $48(19.67)$ & \\
\hline & $\begin{array}{c}\text { Rs } 40,000- \\
50,000\end{array}$ & $120(15.87)$ & $4(3.33)$ & $10(8.33)$ & $10(8.33)$ & $70(58.33)$ & $26(21.67)$ & \\
\hline & $>$ Rs 50,000 & $46(6.08)$ & $0(0)$ & $0(0)$ & $4(8.7)$ & $32(69.57)$ & $10(21.74)$ & \\
\hline \multirow{4}{*}{$\begin{array}{l}\text { Brand } \\
\text { purchasing } \\
\text { Experience }\end{array}$} & $0-2$ Years & $278(36.77)$ & $0(0)$ & $8(2.88)$ & $28(10.07)$ & $200(71.94)$ & $42(15.11)$ & \multirow{4}{*}{$\begin{array}{c}27.984, \mathrm{df} 1 \\
2,<0.05\end{array}$} \\
\hline & $2-5$ Years & $346(45.77)$ & $6(1.73)$ & $19(5.49)$ & $31(8.96)$ & $217(62.72)$ & $73(21.1)$ & \\
\hline & 5-10 Years & $62(8.2)$ & $0(0)$ & $4(6.45)$ & $2(3.23)$ & $34(54.84)$ & $22(35.48)$ & \\
\hline & $>10$ Years & $70(9.26)$ & $0(0)$ & $2(2.86)$ & $8(11.43)$ & $44(62.86)$ & $16(22.86)$ & \\
\hline
\end{tabular}

\section{Analysis:}

The cross-tabulation results for consumers perception on Perceived Usefulness of Social Media Marketing in Brand purchasing with the qualification of the consumers has revealed that $(22.225, \mathrm{df} 8,<0.05)$ there is a significant association between them. The cross-tabulation results for consumers perception on Perceived Usefulness of Social Media Marketing in Brand purchasing with the monthly income revealed that $(24.990, \mathrm{df} 12,<0.05)$ there is a significant association between them. The cross-tabulation results for consumers perception on Perceived Usefulness of Social Media Marketing in Brand purchasing with the years of Brand purchase Experience with the question asked revealed that $(27.984, \mathrm{df} 12,<0.05)$ there is a significant association between them. 
H2: Related Advantage of Social Media Marketing in Brand purchasing.

Table 2: Related Advantage of Social Media Marketing in Brand purchasing

\begin{tabular}{|c|c|c|c|c|c|c|c|c|}
\hline \multicolumn{2}{|c|}{ Demographic Description } & $\begin{array}{c}\text { Total } \\
\text { sample } \\
n=756\end{array}$ & $\begin{array}{c}\text { Very } \\
\text { much } \\
\text { Unlikely }\end{array}$ & Unlikely & Neutral & Likely & $\begin{array}{c}\text { Very } \\
\text { much } \\
\text { Likely }\end{array}$ & Chi Sq \\
\hline \multirow{3}{*}{$\begin{array}{l}\text { Qualificati } \\
\text { on }\end{array}$} & SSC & $466(61.64)$ & $4(0.86)$ & $15(3.22)$ & $57(12.23)$ & $311(66.74)$ & $79(16.95)$ & \multirow{3}{*}{$\begin{array}{l}7.188, \mathrm{df} \\
8,>0.05\end{array}$} \\
\hline & Graduates & $252(33.33)$ & $2(0.79)$ & $8(3.17)$ & $25(9.92)$ & $157(62.3)$ & $60(23.81)$ & \\
\hline & $\mathrm{PG}$ & $38(5.03)$ & $0(0)$ & $0(0)$ & $5(13.16)$ & $24(63.16)$ & $9(23.68)$ & \\
\hline \multirow{4}{*}{$\begin{array}{l}\text { Monthly } \\
\text { Income }\end{array}$} & $\begin{array}{c}\text { Rs. } 20,000- \\
30,000\end{array}$ & $346(45.77)$ & $0(0)$ & $13(3.76)$ & $34(9.83)$ & $234(67.63)$ & $65(18.79)$ & \multirow{4}{*}{$\begin{array}{c}12.862, \mathrm{~d} \\
\mathrm{f} 12,>0.0 \\
5\end{array}$} \\
\hline & $\begin{array}{c}\text { Rs 30,000- } \\
40,000\end{array}$ & $244(32.28)$ & $4(1.64)$ & $6(2.46)$ & $31(12.7)$ & $154(63.11)$ & $49(20.08)$ & \\
\hline & $\begin{array}{c}\text { Rs 40,000- } \\
50,000\end{array}$ & $120(15.87)$ & $2(1.67)$ & $4(3.33)$ & $18(15)$ & $72(60)$ & $24(20)$ & \\
\hline & $>$ Rs 50,000 & $46(6.08)$ & $0(0)$ & $0(0)$ & $4(8.7)$ & $32(69.57)$ & $10(21.74)$ & \\
\hline \multirow{4}{*}{$\begin{array}{l}\text { Brand } \\
\text { purchasing } \\
\text { Experience }\end{array}$} & $0-2$ Years & $278(36.77)$ & $0(0)$ & $6(2.16)$ & $40(14.39)$ & $193(69.42)$ & $39(14.03)$ & \multirow{4}{*}{$\begin{array}{c}25.961,1 \\
2 \mathrm{df},<0.0 \\
5\end{array}$} \\
\hline & $2-5$ Years & $346(45.77)$ & $6(1.73)$ & $13(3.76)$ & $39(11.27)$ & $211(60.98)$ & $77(22.25)$ & \\
\hline & 5-10 Years & $62(8.2)$ & $0(0)$ & $2(3.23)$ & $2(3.23)$ & $46(74.19)$ & $12(19.35)$ & \\
\hline & $>10$ Years & $70(9.26)$ & $0(0)$ & $2(2.86)$ & $6(8.57)$ & $42(60)$ & $20(28.57)$ & \\
\hline
\end{tabular}

\section{Analysis:}

The cross-tabulation results for Related Advantage of Social Media Marketing in Brand purchasing with the qualification of the consumers has revealed that $(7.188, \mathrm{df} 8,>0.05)$ there is no significant association between them. The cross-tabulation results for Related Advantage of Social Media Marketing in Brand purchasing with the monthly income revealed that $(12.862, \mathrm{df} 12,>0.05)$ there is no significant association between them. The crosstabulation results for Related Advantage of Social Media Marketing in Brand purchasing with the years of Brand purchase Experience with the question asked revealed that $(25.961,12 \mathrm{df},<0.05)$ there is a significant association between them.

H3: Perceived Ease of use of Social Media Marketing in Brand purchasing.

Table 3: Perceived Ease of use of Social Media Marketing in Brand purchasing.

\begin{tabular}{|c|c|c|c|c|c|c|c|c|}
\hline \multicolumn{2}{|c|}{ Demographic Description } & $\begin{array}{c}\text { Total } \\
\text { sample } \\
\text { n=756 }\end{array}$ & $\begin{array}{c}\text { Very } \\
\text { much } \\
\text { Unlikely }\end{array}$ & Unlikely & Neutral & Likely & $\begin{array}{c}\text { Very } \\
\text { much } \\
\text { Likely }\end{array}$ & Chi Sq \\
\hline \multirow{3}{*}{ Qualification } & $\mathrm{SSC}$ & $466(61.64)$ & $2(0.43)$ & $6(1.29)$ & $49(10.52)$ & $348(74.68)$ & $61(13.09)$ & \multirow{3}{*}{$\begin{array}{c}4.842, \mathrm{df} 8 \\
,>0.05\end{array}$} \\
\hline & Graduates & $252(33.33)$ & $0(0)$ & $4(1.59)$ & $25(9.92)$ & $187(74.21)$ & $36(14.29)$ & \\
\hline & $\mathrm{PG}$ & $38(5.03)$ & $0(0)$ & $0(0)$ & $7(18.42)$ & $25(65.79)$ & $6(15.79)$ & \\
\hline \multirow{4}{*}{$\begin{array}{l}\text { Monthly } \\
\text { Income }\end{array}$} & $\begin{array}{c}\text { Rs. } 20,000- \\
30,000\end{array}$ & $346(45.77)$ & $0(0)$ & $2(0.58)$ & $38(10.98)$ & $261(75.43)$ & $45(13.01)$ & \multirow{4}{*}{$\begin{array}{c}10.013, \mathrm{df} \\
12,>0.05\end{array}$} \\
\hline & $\begin{array}{c}\text { Rs } 30,000- \\
40,000\end{array}$ & $244(32.28)$ & $2(0.82)$ & $6(2.46)$ & $25(10.25)$ & $177(72.54)$ & $34(13.93)$ & \\
\hline & $\begin{array}{c}\text { Rs 40,000- } \\
50,000\end{array}$ & $120(15.87)$ & $0(0)$ & $2(1.67)$ & $12(10)$ & $90(75)$ & $16(13.33)$ & \\
\hline & $>$ Rs 50,000 & $46(6.08)$ & $0(0)$ & $0(0)$ & $6(13.04)$ & $32(69.57)$ & $8(17.39)$ & \\
\hline \multirow{4}{*}{$\begin{array}{l}\text { Brand } \\
\text { purchasing } \\
\text { Experience }\end{array}$} & $0-2$ Years & $278(36.77)$ & $0(0)$ & $2(0.72)$ & $34(12.23)$ & $215(77.34)$ & $27(9.71)$ & \multirow{4}{*}{$\begin{array}{c}16.015, \mathrm{df} \\
12,>0.05\end{array}$} \\
\hline & $2-5$ Years & $346(45.77)$ & $2(0.58)$ & $6(1.73)$ & $37(10.69)$ & $247(71.39)$ & $54(15.61)$ & \\
\hline & 5-10 Years & $62(8.2)$ & $0(0)$ & $2(3.23)$ & $2(3.23)$ & $48(77.42)$ & $10(16.13)$ & \\
\hline & $>10$ Years & $70(9.26)$ & $0(0)$ & $0(0)$ & $8(11.43)$ & $50(71.43)$ & $12(17.14)$ & \\
\hline
\end{tabular}

\section{Analysis:}

The cross-tabulation results for Perceived Ease of use of Social Media Marketing in Brand purchasing has revealed that $(4.842, \mathrm{df} 8,>0.05)$ there is no significant association between them. The cross-tabulation results for Perceived Ease of use of Social Media Marketing in Brand purchasing with the monthly income revealed that $(10.013, \mathrm{df} 12,>0.05)$ there is no significant association between them. The crosstabulation results for Perceived Ease of use of Social Media

Marketing in Brand purchasing with the years of Brand purchase Experience with the question asked revealed that $(16.015, \mathrm{df1} 2,>0.05)$ there is no significant association between them. 
H4: Intention to Use Social Media Marketing in Brand purchasing.

Table 4: Intention to Use Social Media Marketing in Brand purchasing

\begin{tabular}{|c|c|c|c|c|c|c|c|c|}
\hline \multicolumn{2}{|c|}{ Demographic Description } & \multirow{2}{*}{$\begin{array}{c}\begin{array}{c}\text { Total } \\
\text { sample } \\
\mathbf{n}=\mathbf{7 5 6}\end{array} \\
466(61.64)\end{array}$} & \multirow{2}{*}{$\begin{array}{c}\begin{array}{c}\text { Very } \\
\text { much }\end{array} \\
\text { Unlikely }\end{array}$} & \multirow{2}{*}{$\begin{array}{l}\text { Unlikely } \\
19(4.08)\end{array}$} & \multirow{2}{*}{$\begin{array}{c}\text { Neutral } \\
51(10.94)\end{array}$} & \multirow{2}{*}{$\begin{array}{c}\text { Likely } \\
323(69.31)\end{array}$} & \multirow{2}{*}{$\begin{array}{c}\begin{array}{c}\text { Very } \\
\text { much }\end{array} \\
\text { Likely } \\
71(15.24)\end{array}$} & \multirow{4}{*}{$\begin{array}{c}\text { Chi Sq } \\
9.597, \text { df } \\
8,<0.05\end{array}$} \\
\hline \multirow{3}{*}{ Qualification } & SSC & & & & & & & \\
\hline & Graduates & $252(33.33)$ & $2(0.79)$ & $8(3.17)$ & $25(9.92)$ & $165(65.48)$ & $52(20.63)$ & \\
\hline & PG & $38(5.03)$ & $0(0)$ & $0(0)$ & $8(21.05)$ & $23(60.53)$ & $7(18.42)$ & \\
\hline \multirow{4}{*}{$\begin{array}{l}\text { Monthly } \\
\text { Income }\end{array}$} & $\begin{array}{c}\text { Rs. 20,000- } \\
30,000\end{array}$ & $346(45.77)$ & $0(0)$ & $13(3.76)$ & $37(10.69)$ & $243(70.23)$ & $53(15.32)$ & \multirow{4}{*}{$\begin{array}{c}10.493, \mathrm{~d} \\
\mathrm{f} 12,<0.0 \\
5\end{array}$} \\
\hline & $\begin{array}{c}\text { Rs 30,000- } \\
40,000\end{array}$ & $244(32.28)$ & $2(0.82)$ & $8(3.28)$ & $29(11.89)$ & $158(64.75)$ & $47(19.26)$ & \\
\hline & $\begin{array}{c}\text { Rs 40,000- } \\
50,000\end{array}$ & $120(15.87)$ & $2(1.67)$ & $6(5)$ & $12(10)$ & $78(65)$ & $22(18.33)$ & \\
\hline & $>\operatorname{Rs} 50,000$ & $46(6.08)$ & $0(0)$ & $0(0)$ & $6(13.04)$ & $32(69.57)$ & $8(17.39)$ & \\
\hline \multirow{4}{*}{$\begin{array}{l}\text { Brand } \\
\text { purchasing } \\
\text { Experience }\end{array}$} & $0-2$ Years & $278(36.77)$ & $0(0)$ & $10(3.6)$ & $32(11.51)$ & $202(72.66)$ & $34(12.23)$ & \multirow{4}{*}{$\begin{array}{c}18.180, \mathrm{~d} \\
\mathrm{f} 12,<0.0 \\
5\end{array}$} \\
\hline & 2-5 Years & $346(45.77)$ & $4(1.16)$ & $15(4.34)$ & $38(10.98)$ & $221(63.87)$ & $68(19.65)$ & \\
\hline & 5-10 Years & $62(8.2)$ & $0(0)$ & $0(0)$ & $4(6.45)$ & $44(70.97)$ & $14(22.58)$ & \\
\hline & $>10$ Years & $70(9.26)$ & $0(0)$ & $2(2.86)$ & $10(14.29)$ & $44(62.86)$ & $14(20)$ & \\
\hline
\end{tabular}

\section{Analysis:}

The cross-tabulation results for Intention to Use Social Media Marketing in Brand purchasing with the qualification of the consumers has revealed that $(9.597, \mathrm{df} 8,<0.05)$ there is no significant association between them. The crosstabulation results for consumers Intention to Use Social Media Marketing in Brand purchasing with the monthly income revealed that $(10.493, \mathrm{df} 12,<0.05)$ there is no significant association between them. The cross-tabulation results for Intention to Use Social Media Marketing in Brand purchasing with the years of Brand purchase Experience with the question asked revealed that $(18.180$, df12, <0.05) there is no significant association between them.

\section{LIMITATIONS AND SUGGESTIONS FOR FUTURE}

Promoting the fashion brands on all the social network platforms is important but considering the preferences of male and female which are different in my study prompting means fashion brand in Facebook and woman fashion brands in Instagram will make them expose to their favourite brands. Female prefer shopping next to entertainment in social networking campaigns. Social networking sites have a positive impact on the consumer purchase intention therefore by providing relevant and genuine content the trust and loyalty of the customers can be enhanced greatly.

\section{CONCLUSION}

The purpose of this research was to explore the ways social network marketing of fashion brands and consumer engagement levels affects the consumer purchase intention.
In order to accomplish this, I performed exploratory research regarding social networking campaigns and consumer engagement and consumer behaviour towards fashion brand in online. Based on my understandings I prepared a survey which includes scale related to my objectives. Results indicate that social network marketing and consumer engagement are showing impact on the consumer purchase intention. Based up on income, education and engagement people are using social media and also engaging themselves by following the fashion brands in social media but percentage of people who are purchasing is less when compared to the engagement levels. They also should utilize these platforms to not only share discounts and promotions, but also stay in touch with consumers and build a connection with their consumers.

\section{REFERENCES}

1. Abu Bashar, I. A. (2015). Effectiveness of the social media as a marketing tool: An empirical study. International journal of marketing, financial services and management research.

2. Adnan Veysel Ertemel, A. A. (2016). The Role Of Social Media Advertising In Consumer Buying. International Journal of Commerce and Finance, II(1), 81-89.

3. Hofman-Kohlmeyer1, M. (2017). Customer Engagement With A Brand In The Context. Cbu International Conference On Innovations In Science And Education, 172-177.

4. Katarzyna Żyminkowska, T. Ż. (2017). Effects of customer engagement behavior. Journal of Economics and Management, 28, 133-154.

5. Maoyan, Z. S. (2014). Consumer Purchase Intention Research Based on Social Media Marketing. 
International Journal of Business and Social Science, 92 97.

6. Mirza Ashfaq Ahmed, Z. Z. (2014). Role of social media marketing to enhance CRM and brand equity in terms. Asian Journal Of Management Research, IV(3), 533-549.

7. Neti, M. S. (2011). Social Media And Its Role In Marketing. International Journal of Enterprise Computing and B International Journal of Enterprise Computing and Business Systems ting and Business Systems business Systems, I(2), 1-16.

8. Susanti, C. E. (2017). Influence of Social Networks and Social media towards apparel purchase decision Adolescents in East java. International Journal of Supply Chain Management, VI(4), 224-233.

9. Vivek, B. M. (2012). Customer Engagement: Exploring Customer Relationships Beyond Purchase. The Journal of Marketing Theory and Practice, 127-145.

10. Zulqurnain ALI, M. A. (2016). To Assess the Impact of Social Media Marketing on Consumer. International Journal of Academic Research in Accounting, Finance and Management Sciences, 6, 69-77. 